\title{
Nutrient Deficiencies Are Key Constraints to Grain Legume Productivity on "Non-responsive" Soils in Sub-Saharan Africa
}

OPEN ACCESS

Edited by:

Andrews Opoku,

Kwame Nkrumah University of

Science and Technology, Ghana

Reviewed by:

Radha Prasanna

Indian Agricultural Research Institute

(ICAR), India

Rechiatu Asei,

Sunyani Technical University, Ghana

*Correspondence:

Frederick P. Baijukya

f.baijukya@cgiar.org

orcid.org/0000-0003-2586-2013

tThese authors have contributed equally to this work and share first authorship

Specialty section:

This article was submitted to Land, Livelihoods and Food Security, a section of the journal

Frontiers in Sustainable Food Systems

Received: 10 March 2021 Accepted: 18 October 2021 Published: 10 November 2021

Citation:

Baijukya FP, Van Heerwaarden J, Franke AC, Van den Brand GJ, Foli S, Keino L, Seitz T, Servan L, Vanlauwe $B$ and Giller KE (2021) Nutrient

Deficiencies Are Key Constraints to Grain Legume Productivity on

"Non-responsive" Soils in Sub-Saharan Africa.

Front. Sustain. Food Syst. 5:678955.

doi: 10.3389/fsufs.2021.678955

\section{Frederick P. Baijukya ${ }^{1 *}$, Joost Van Heerwaarden ${ }^{2 \dagger}$, Angelinus C. Franke ${ }^{3}$, Greta J. Van den Brand ${ }^{2}$, Samson Foli ${ }^{2}$, Ludy Keino ${ }^{4}$, Thobias Seitz ${ }^{2}$, Lenoir Servan ${ }^{2}$, Bernard Vanlauwe ${ }^{5 t}$ and Ken E. Giller ${ }^{2}$}

${ }^{1}$ International Institute of Tropical Agriculture (IITA), Natural Resource Management Research Area, Dar es Salaam, Tanzania, 2 Plant Production Systems, Wageningen University, Wageningen, Netherlands, ${ }^{3}$ Soil, Crop and Climate Sciences, University of the Free State, Bloemfontein, South Africa, ${ }^{4}$ International Centre for Research in Agroforestry (ICRAF), Soil and Plant Analysis Laboratory, Nairobi, Kenya, ${ }^{5}$ International Institute of Tropical Agriculture (IITA), Natural Resource Management Research Area, Nairobi, Kenya

Leguminous plants are known to require phosphorus fertilizers and inoculation with nitrogen fixing rhizobia for optimum yield but other nutrients may also be lacking. In this study, the most limiting nutrients for legume growth were determined in soils where the crops had not responded to $\mathrm{P}$ and rhizobial inoculation in field trials, using the double pot technique. Soils were collected from 17 farmers' fields in West Kenya, Northern Nigeria, Eastern and Southern Rwanda, South-west and North-west Sierra Leone. Plant growth and mean biomass were measured on soils to which a full nutrient solution, containing phosphorus $(\mathrm{P})$, potassium $(\mathrm{K})$, magnesium $(\mathrm{Mg})$, sulfur $(\mathrm{S})$ and micronutrients (MN) were added, and which were compared to a control (no nutrient added), and individual omissions of each nutrient. The relationship between soil properties and nutrient deficiencies was explored. Nutrient limitations were found to differ between soils, both within and across countries. Generally, each soil was potentially deficient in at least one nutrient, with $\mathrm{K}, \mathrm{P}, \mathrm{Mg}, \mathrm{MN}$ and $\mathrm{S}$ emerging as most limiting in $88,65,59,18$, and $12 \%$ of tested soils, respectively. While $\mathrm{K}$ was the most limiting nutrient in soils from Kenya and Rwanda, $P$ was most limiting in soils from Nigeria. $P$ and $K$ were equally limiting in soils from Sierra Leone. Mg was found limiting in two soils from Kenya and three soils from Rwanda and one soil each in Nigeria and Sierra Leone. Micronutrients were found to be limiting in one soil from Nigeria and one soil from Rwanda. Estimates of nutrient deficiency using growth and mean biomass were found to be correlated with each other although the latter proved to be a more sensitive measure of deficiency. With few exceptions, the relation between soil parameters and nutrient deficiencies was weak and there were no significant relations between deficiency of specific nutrients and the soil content of these elements. Although our results cannot be translated directly to the field, they confirm that individual and multiple nutrient deficiencies were common in these "non-responsive" soils and may have contributed to reported low yields. This highlights the need for balanced nutrition in legume production in SSA.

Keywords: missing nutrients, sustainability, double-pot technique, balanced nutrition, enhanced productivity, smallholder farms 


\section{INTRODUCTION}

Grain legumes, particularly cowpea (Vigna unguiculata (L.) Walp), groundnut (Arachis hypogaea L.), soybean (Glycine max L. Merril) and common bean (Phaseolus vulgaris L.), play important roles in the livelihoods of smallholder farmers in sub-Saharan Africa (SSA) (Nedumaran et al., 2015; Vanlauwe et al., 2019). Household surveys generally identify grain legumes as an affordable source of dietary protein in the diets of the poor (Latham, 1997) and as a source of cash income, especially for women (Odendo et al., 2011). Across the savannah regions of West Africa cowpea and groundnut residues are fed to livestock as protein supplements when animal feeds are in short supply (Tarawali and Mohamed-Saleem, 1995; Savadogo et al., 2000) while rotation of grain legumes with cereals has been reported to enhance cereal yields on smallholder farms (Franke et al., 2017). Further, legumes are also known to be a critical source of folic acid, a necessary nutrient for prenatal and early childhood health, thus a potent tool to fight childhood stunting (Smith and Haddad, 2014; Bevis, 2015).

Despite their importance, legume yields on smallholder farms remain far below their potential, largely because the crops are grown on infertile soils without adding fertilizer (Sanchez et al., 1997). Integrated soil fertility management (ISFM) interventions, including use of $\mathrm{P}$ fertilizers, animal manure, composts, inoculants and seeds of improved varieties can increase productivity of grain legumes (Giller et al., 2013) but yield responses measured in field experiments are known to vary considerably (Ronner et al., 2016; Van Heerwaarden et al., 2018). Such variation may partly reflect the effect of additional nutrient constraints, something which has been observed explicitly in crops such as maize (Franke et al., 2008). The fact that local deficiencies of specific soil nutrients can limit crop yields and fertilizer responses would argue for more frequent field evaluations to detect such problems, in order to set priorities for future soil fertility management in the areas under study. Unfortunately, such in situ studies are typically expensive and hard to implement due to logistical, material and environmental constraints (Gibson et al., 1999). As a complement to such studies therefore, nutrient omission experiments performed in pots under controlled greenhouse conditions have been proposed as a powerful and cost-effective tool to identify key nutrient deficiencies in soils (Janssen, 1990). Although the transferability of results from such studies to natural conditions may be limited, because the sampled soil may not fully represent the field conditions, the technique has the advantage of being relatively quick and inexpensive, allowing soil limiting nutrients to be examined individually, with sufficient replication and in absence of complicating factors such as water stress and the occurrence of pests and diseases (Gibson et al., 1999).

This paper analyses a set of soils from selected sites in western Kenya, Nigeria, Sierra Leone, and Rwanda where grain legumes had failed to respond to added P fertilizer or rhizobial inoculation-so-called "non-responsive" soils (Vanlauwe et al., 2015). Our aim was to identify specific nutrient deficiencies that may constrain legume growth and to provide information that may help design future field-based studies into appropriate soil fertility amendments in the region.

\section{MATERIALS AND METHODS}

\section{Data Sources}

A database containing 672 data points (soil-nutrient-growth period combinations) was compiled from five greenhousenutrient omission experiments conducted at the International Institute of Tropical Agriculture (IITA)-Kano station in Nigeria (in 2012), the Rwandan Agriculture Board Rubona Research Station (2013), the Sierra Leone Agricultural Research Institute (SLARI) in Sierra Leone (2013) and the University of Eldoret in Kenya (2015), all employing a double pot technique. Results from the experiment in Kenya were reported by Keino et al. (2015), and are included in the present analysis for cross country comparison.

\section{The Double-Pot Method}

The double pot method is a rapid procedure used in diagnosing deficient plant nutrients in soils (Janssen, 1990). The set-up of the pots is as presented in Figure 1. Seedlings of test plants are sown in restricted quantity of soil placed in the upper pot (Pot 1), which has a gauze at the bottom. The growing roots pass through the gauze and reach the nutrient solution (in Pot 2) in which the desired test nutrient is omitted. The soil in Pot 1 is kept moist by irrigating with distilled water through a pipe filled with quartz. In this set up, two sources of nutrients are provided, which the plant can access simultaneously. The first is the test-soil itself, and the second the defined nutrient solution. By omitting one selected nutrient in the solution, the plant is forced to draw this nutrient from the soil. If the soil does not supply sufficient of this omitted nutrient, the plant will suffer from deficiency symptoms, such as limited growth and leaf deficiency symptoms. Such symptoms are visible in early growth stages, so that conclusions about further development and yield can be inferred after a few weeks.

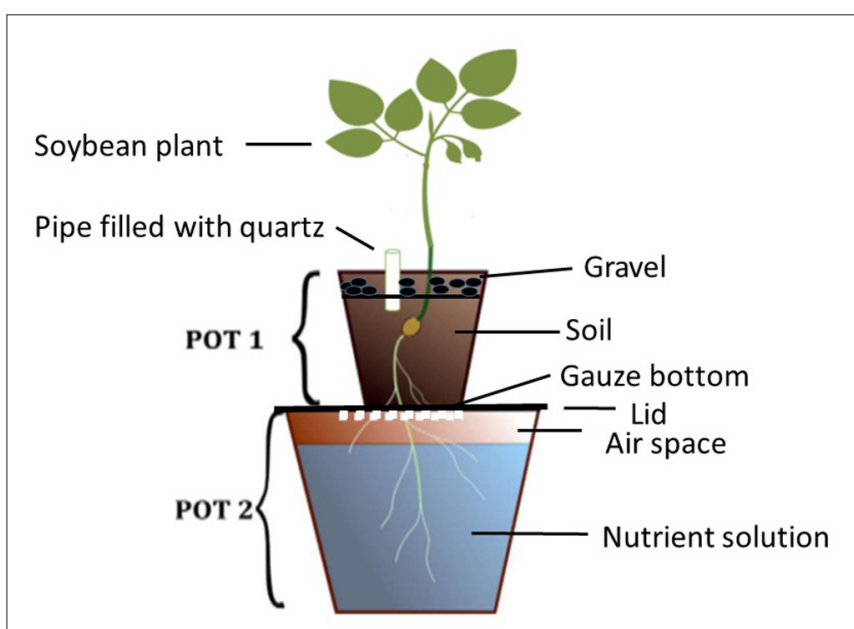

FIGURE 1 | Illustration of the setup of the double pot technique. 


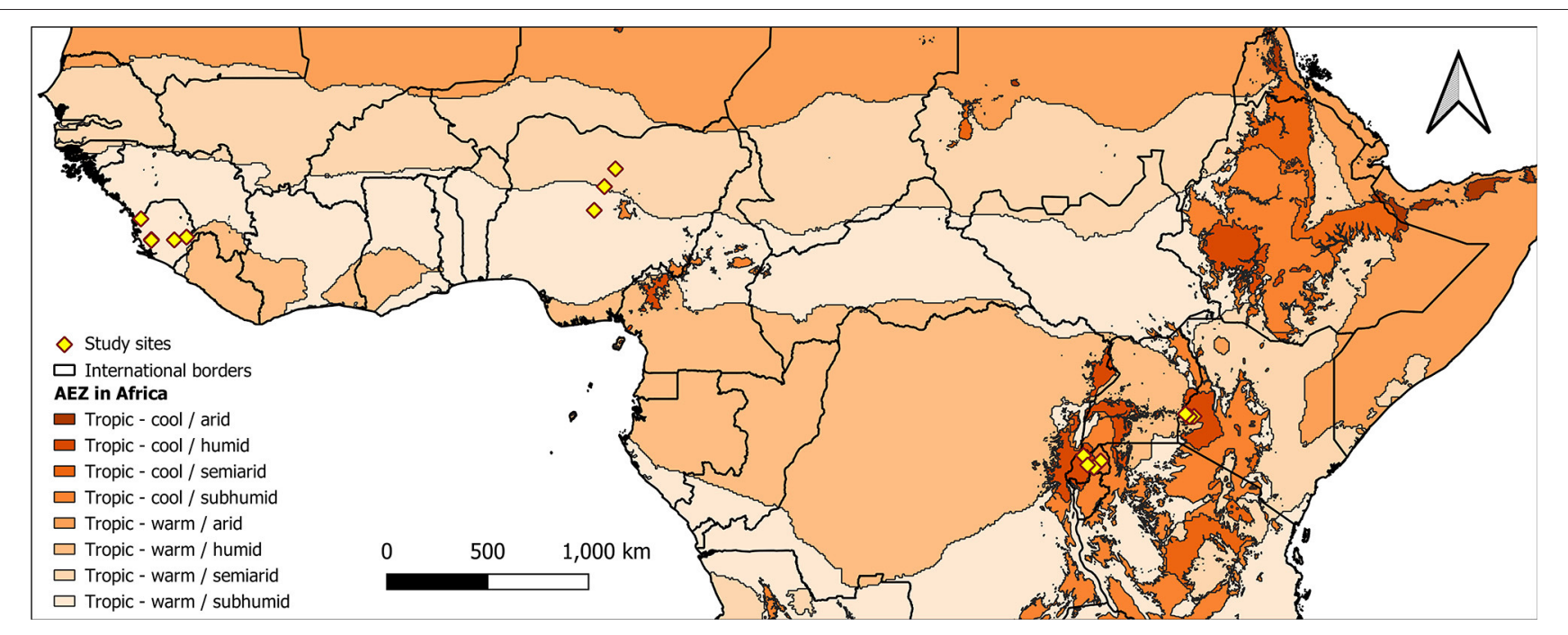

FIGURE 2 | Map showing location of farms (yellow diamond shape) where soils used in this study were collected from. Colored shading marks different agro-ecological zones.

\section{Experimental Soils, Sampling, and Analysis}

Soils were collected from farmers' fields in Western Kenya (5 soils); Northern Nigeria (3 soils); the Northern (1 soil), Southern ( 2 soils) and Eastern (1 soil) provinces of Rwanda; Southwest (2 soils), and North-west (3 soils) Sierra Leone (Figure 2). Areas chosen for soil sampling were among the impact zones in which the N2Africa Project (www.n2africa.com) operated. In Kenya, Nigeria and Rwanda, previous agronomic experiments conducted in these soils (between 2009 and 2013) indicated poor yields of grain legumes with insignificant response to $\mathrm{P}$ fertilization and rhizobia inoculation (Van Heerwaarden et al., 2018). In Sierra Leone, soils were collected from fields where researchers suspected that nutrient deficiencies were limiting cowpea and soybean. The names of locations, GPS readings of fields and types of legumes grown prior to soil sampling are summarized in Table 1.

From each field $\sim 60-70 \mathrm{~kg}$ of top soil $(0-20 \mathrm{~cm})$ was collected at $15-20$ points in a zig-zag pattern across the field, using a spade or a hand hoe. The soil portions from each field were mixed to form a composite representative sample, air-dried, sieved to pass a $5 \mathrm{~mm}$ mesh then put in pots, each carrying $250 \mathrm{~g}$. Roughly $200 \mathrm{~g}$ of soil per site was taken for chemical and physical analysis at Crop Nutrition Laboratory Services (CROPNUTS) in Nairobi, Kenya (for soils collected in Kenya and Rwanda); or the IITA-analytical laboratory at Ibadan, Nigeria (for soils collected in Nigeria and Sierra Leone). Soils were analyzed for particle sizes (sand, silt, and clay) using the hydrometer method (Gee and Or, 2002), $\mathrm{pH}$ in a 1:2 soil water volume ratio, total $\mathrm{N}$ using Kjeldahl method, soil organic carbon (SOC) by WalkleyBlack dichromate oxidation method Nelson and Sommers (1982) and available P by Olsen method (Nelson and Sommers, 1982). Exchangeable cations ( $\mathrm{Ca}, \mathrm{Mg}$, and $\mathrm{K}$ ) were determined after Mehlich 3 extraction (Mehlich, 1984) at CROPNUTS, whereas the $0.1 \mathrm{M} \mathrm{NH}_{4} \mathrm{OACc}$ extraction method (Thomas, 1982) was used at IITA-Ibadan.
TABLE 1 | Names of locations of farms where experimental soils were collected and corresponding legume grown on field before soil sampling.

\begin{tabular}{|c|c|c|c|c|}
\hline \multirow[t]{2}{*}{ Country } & \multirow[t]{2}{*}{ Site } & \multicolumn{2}{|c|}{ GPS reading } & \multirow[t]{2}{*}{ Legume planted } \\
\hline & & Latitude & Longitude & \\
\hline \multirow[t]{3}{*}{ Nigeria } & Kachia & $9.52083^{\circ}$ & $7.57065^{\circ}$ & Cowpea \\
\hline & Soba & $10.59316^{\circ}$ & $8.03064^{\circ}$ & Cowpea \\
\hline & Garko & $11.39364^{\circ}$ & $8.53008^{\circ}$ & Soybean \\
\hline \multirow[t]{5}{*}{ Kenya } & Masaba & $0.19997^{\circ}$ & $34.46061^{\circ}$ & Soybean \\
\hline & Kakamega1 & $0.20722^{\circ}$ & $34.67233^{\circ}$ & Common bean \\
\hline & Kakamega 2 & $0.20406^{\circ}$ & $34.66817^{\circ}$ & Common bean \\
\hline & Butere & $0.19759^{\circ}$ & $34.46581^{\circ}$ & Soybean \\
\hline & Butula & $0.31994^{\circ}$ & $34.28025^{\circ}$ & Soybean \\
\hline \multirow[t]{4}{*}{ Rwanda } & Cyabingo & $1.56732^{\circ}$ & $29.67895^{\circ}$ & Common bean \\
\hline & Kawangire & $1.80811^{\circ}$ & $30.45027^{\circ}$ & Common bean \\
\hline & Nyarubaka & $2.10722^{\circ}$ & $30.14798^{\circ}$ & Soybean \\
\hline & Musambira & $1.99203^{\circ}$ & $29.86221^{\circ}$ & Soybean \\
\hline \multirow[t]{5}{*}{ Sierra Leone } & Gbombtrait & $8.20059^{\circ}$ & $-12.43631^{\circ}$ & Soybean \\
\hline & Bondajuma & $8.31088^{\circ}$ & $-10.84820^{\circ}$ & - \\
\hline & Kodenbotihun & $8.16726^{\circ}$ & $-12.43614^{\circ}$ & Cowpea \\
\hline & Foya Junction & $8.183589^{\circ}$ & $-11.40030^{\circ}$ & - \\
\hline & MeriCurve & $9.13493^{\circ}$ & $-12.90843^{\circ}$ & Cowpea \\
\hline
\end{tabular}

Most soils were acidic ( $\mathrm{pH} 4.2$ to 5.5), except soil Kawangile and soil Nyarubaka from Rwanda and soil Garko from Nigeria, had a pH between 6.0 and 6.1 (Table 2). It is difficult to assign minimum or maximum threshold values for soil organic carbon (SOC) as the values depend very much on texture. However, adapting criteria from Landon (1991) to indicate low, medium and high levels of SOC for top soils of different texture in the tropics, it was low for soils in Kenya (except soil Kakamega 2) and soils in Nigeria, but was high for soils in Rwanda (except soil 
TABLE 2 | Top $(0-20 \mathrm{~cm})$ soil chemical and physical properties of the soils used in the experiments.

\begin{tabular}{|c|c|c|c|c|c|c|c|c|c|c|c|c|}
\hline \multirow[t]{2}{*}{ Country of origin } & \multirow[t]{2}{*}{ Site } & \multirow[t]{2}{*}{$\mathrm{pH}$} & \multirow{2}{*}{$\begin{array}{c}\text { Total N } \\
\text { (\%) }\end{array}$} & \multirow{2}{*}{$\begin{array}{l}\text { OC } \\
(\%)\end{array}$} & \multirow{2}{*}{$\begin{array}{l}\text { Avail. P } \\
\left(\mathbf{m g ~ k g}{ }^{-1}\right)\end{array}$} & \multicolumn{3}{|c|}{ Exchangeable cations $\left(\mathrm{cmol}_{\mathrm{c}} \mathbf{k g}^{-1}\right)$} & \multicolumn{3}{|c|}{ Particle size $\left(\mathbf{g ~ k g}^{-1}\right)$} & \multirow[t]{2}{*}{ Textural class ${ }^{\star}$} \\
\hline & & & & & & $\mathbf{K}$ & $\mathrm{Ca}$ & Mg & Clay & Sand & Silt & \\
\hline \multirow[t]{3}{*}{ Nigeria } & Kachia & 5.1 & 0.09 & 0.93 & 1.0 & 0.16 & 1.93 & 0.95 & 330 & 470 & 200 & SCL \\
\hline & Soba & 5.5 & 0.07 & 0.71 & 2.3 & 0.10 & 1.13 & 0.65 & 170 & 470 & 360 & $L$ \\
\hline & Garko & 6.0 & 0.05 & 0.55 & trace & 0.12 & 1.45 & 0.78 & 110 & 690 & 200 & SL \\
\hline \multirow[t]{5}{*}{ Kenya } & Masaba & 4.7 & 0.13 & 1.50 & 4.4 & 0.16 & 1.10 & 0.51 & 300 & 540 & 160 & SCL \\
\hline & Kakamega 1 & 5.1 & 0.24 & 3.13 & 7.3 & 0.18 & 4.34 & 1.70 & 320 & 480 & 200 & SCL \\
\hline & Kakamega 2 & 5.0 & 0.20 & 2.59 & 4.6 & 0.17 & 3.22 & 0.93 & 320 & 520 & 160 & SCL \\
\hline & Butere & 4.9 & 0.13 & 1.25 & 2.1 & 0.10 & 1.03 & 0.39 & 180 & 600 & 220 & SL \\
\hline & Butula & 5.0 & 0.15 & 1.58 & 6.2 & 0.16 & 2.49 & 0.98 & 240 & 580 & 140 & SCL \\
\hline \multirow[t]{4}{*}{ Rwanda } & Cyabingo & 5.0 & 0.12 & 2.33 & 8.4 & 0.12 & 1.30 & 0.22 & 329 & 451 & 220 & SCL \\
\hline & Kawangire & 6.0 & 0.21 & 3.48 & 83.0 & 0.12 & 2.62 & 0.51 & 489 & 371 & 140 & $\mathrm{C}$ \\
\hline & Nyarubaka & 6.1 & 0.20 & 2.27 & 61.1 & 0.06 & 0.51 & 0.14 & 209 & 672 & 120 & SCL \\
\hline & Musambira & 4.6 & 0.09 & 1.42 & 13.2 & 0.09 & 0.08 & 0.02 & 409 & 551 & 40 & SC \\
\hline \multirow[t]{5}{*}{ Sierra Leone } & Gbombtrait & 4.9 & 0.31 & 3.00 & 3.4 & 0.31 & 3.30 & 0.71 & 220 & 600 & 180 & SCL \\
\hline & Bondajuma & 5.2 & 0.19 & 2.60 & 3.6 & 0.30 & 3.90 & 0.58 & 200 & 680 & 120 & SCL \\
\hline & Kodenbotihun & 4.5 & 0.18 & 2.40 & 3.3 & 0.17 & 1.60 & 0.38 & 340 & 480 & 180 & SCL \\
\hline & Foya Junction & 4.5 & 0.37 & 2.80 & 10.0 & 0.43 & 3.70 & 0.72 & 240 & 600 & 160 & SCL \\
\hline & MeriCurve & 4.2 & 0.30 & 2.80 & 3.2 & 0.33 & 2.50 & 0.53 & 260 & 600 & 140 & SCL \\
\hline
\end{tabular}

Textural class; C, Clay, SC, Sandy-Clay; SCL, Sandy-Clay-Loam; SL, Sandy-Loam; L, Loam; S, Sandy.

Musambira) and soils in Sierra Leone. All soils were low in $\mathrm{N}$, $\mathrm{K}, \mathrm{Mg}$ and $\mathrm{Ca}$ applications as these nutrients were available in low levels. In most soils, except soils Kawangire and Nyarubaka from Rwanda, available $\mathrm{P}$ was below $10 \mathrm{mg} \mathrm{kg}^{-1}$ indicating that crops would respond to $\mathrm{P}$ fertilizer application (Landon, 1991).

\section{Nutrient Treatments}

Seven N-free nutrient treatments were considered across countries. These included two treatments aimed at establishing the response of soybean to the application of all nutrients minus N: 1. Control (no nutrients added), 2. Complete (P, $\mathrm{K}, \mathrm{Mg}, \mathrm{Ca}, \mathrm{S}$, and a combination of micronutrients (MN) $\mathrm{Mo}, \mathrm{B}, \mathrm{Zn}, \mathrm{Cu}, \mathrm{Mo}$ and $\mathrm{Fe}$ ) added. The remaining five treatments evaluated omission of a single macronutrient and a combination of micronutrients in turn: 3.-P; 4. -K; 5. -Mg; 6. -S; 7. -MN. A -Ca treatment was not included because plant roots cannot not grow in Ca free nutrient solution (Janssen, 1974).

Salts, concentrations, chemical forms and rates of nutrients applied in different experiments are shown in Table 3. In Nigeria the concentration of nutrients was derived from a standard Hoagland's No. 2 solution (Hewitt, 1966). In Kenya, Rwanda and Sierra Leone the concentration of nutrients was derived from a standard Hoagland No. 2 solution in a half dilution and modified for the specific use with soybeans (Paradiso et al., 2012); the ion concentration in the Complete treatment was (in $\mathrm{mM}$ ): P 0.5, $\mathrm{K}$ 3.0, Ca 2.5, Mg 1.0, S 1.0; (in $\mu \mathrm{M}$ ): Fe 60.0, Mn 7.4, Zn 0.96, Cu 1.04, B 7.13, Mo 0.01 .

\section{Experimental Procedures}

Soybean was used as the test plant. Test varieties were TGx17402F for the experiments in Kenya and Rwanda; TGx1448-2E in Nigeria and TGx1951-4F in Sierra Leone. Before sowing, soybean seeds were inoculated with rhizobia inoculant Legumefix (supplied by Legume Technology UK) for experiments in Nigeria, Rwanda and Sierra Leone, and with Biofix (supplied by MEA Kenya ltd) in Kenya. Inoculation followed a two-step method described in Somasegaran and Hoben, 1994. Three to four soybean seeds per pot were sown which were thinned to single uniform plants, five days after emergence (DAE). The top pots were watered daily with distilled water to keep the soils at field capacity. The nutrient solutions (with $\mathrm{pH}$ adjusted between 6.0 and 6.5 using $\mathrm{NaOH}$ ) were added in Pot 2, 5 DAE and renewed every 8-10 days. The experiments were laid out in a completely randomized design (CRD) with four replications, except in Sierra Leone where three replications were used. Experimental factors were soil and nutrient solution. To allow for destructive sampling at 3-4 intervals, an extra 3-4 pots per treatment per replication were included.

\section{Observations, Harvesting, and Measurements}

From 10 days after emergence (DAE) onwards, regular observations were made on the experiments to detect visual nutrient deficiency symptoms in the leaves. Plant growth was determined at three growth periods (Table 4) through destructive sampling by cutting the plants at soil level followed by measuring and comparing shoot dry weight. Fresh weight (FW) was 
TABLE 3 | Salt form and concentrations used to prepare the nitrogen-free nutrient solutions before application to the plants.

\begin{tabular}{|c|c|c|c|c|}
\hline \multirow[t]{2}{*}{ Nutrient } & \multirow[t]{2}{*}{ Compound } & \multicolumn{3}{|c|}{ Concentration (mg /l) } \\
\hline & & Nigeria & Kenya and Rwanda & Sierra Leone \\
\hline \multirow[t]{3}{*}{$\mathrm{P}$} & $\mathrm{K}_{2} \mathrm{HPO}_{4}$ & 200 & - & 102.1 \\
\hline & $\mathrm{H}_{3} \mathrm{PO}_{4}$ & - & 49.0 & - \\
\hline & $\mathrm{H}_{2} \mathrm{NaO}_{4} \mathrm{P} .2 \mathrm{H}_{2} \mathrm{O}$ & - & - & 58.6 \\
\hline \multirow[t]{2}{*}{ K } & $\mathrm{K}_{2} \mathrm{CO}_{3}$ & - & 207.3 & - \\
\hline & $\mathrm{KCl}$ & 750 & - & 447.6 \\
\hline \multirow[t]{3}{*}{$\mathrm{Mg}$} & $\mathrm{MgSO} 4 \cdot 7 \mathrm{H}_{2} \mathrm{O}$ & 200 & 246.4 & 493.0 \\
\hline & $\mathrm{MgCl}_{2} \cdot 6 \mathrm{H}_{2} \mathrm{O}$ (only in-S) & 950 & 203.3 & - \\
\hline & $\mathrm{MgCO}_{3}$ (only in-S) & - & - & 42.2 \\
\hline \multirow[t]{2}{*}{ S } & $\mathrm{MgSO}_{4} \cdot 7 \mathrm{H}_{2} \mathrm{O}$ & - & - & - \\
\hline & $\mathrm{K}_{2} \mathrm{SO}_{4}$ (only in -Mg) & 174 & 174.3 & - \\
\hline \multirow[t]{3}{*}{$\mathrm{Ca}$} & $\mathrm{CaCl}_{2} \cdot 2 \mathrm{H}_{2} \mathrm{O}$ & 1100 & 368.0 & 596.6 \\
\hline & $\mathrm{CaSO}_{4}$ & & - & 435.0 \\
\hline & $\mathrm{CaHPO}_{4} .2 \mathrm{H}_{2} \mathrm{O}$ & 1000 & - & - \\
\hline \multirow[t]{2}{*}{$\mathrm{Mn}$} & $\mathrm{MnCl}_{2} \cdot 4 \mathrm{H}_{2} \mathrm{O}$ & 1.970 & 1.465 & - \\
\hline & $\mathrm{MnSO}_{4} . \mathrm{H}_{2} \mathrm{O}$ & - & - & 3.170 \\
\hline B & $\mathrm{H}_{3} \mathrm{BO}_{3}$ & 2.860 & 0.441 & 1.100 \\
\hline $\mathrm{Cu}$ & $\mathrm{CuSO}_{4} \cdot 5 \mathrm{H}_{2} \mathrm{O}$ & 0.080 & 0.260 & 0.650 \\
\hline $\mathrm{Zn}$ & $\mathrm{ZnSO}_{4} \cdot 7 \mathrm{H}_{2} \mathrm{O}$ & 0.220 & 0.276 & 0.690 \\
\hline \multirow[t]{2}{*}{ Mo } & $\mathrm{Na}_{2} \mathrm{MoO}_{4} \cdot 2 \mathrm{H}_{2} \mathrm{O}$ & 0.140 & 0.002 & - \\
\hline & $(\mathrm{NH} 4)_{6} \mathrm{Mo}_{7} \mathrm{O}_{24}$ & - & - & 0.080 \\
\hline $\mathrm{Fe}$ & $\mathrm{FeCl}_{3}, 6 \mathrm{H}_{2} \mathrm{O}$ & 0.100 & - & 0.100 \\
\hline
\end{tabular}

TABLE 4 | Harvesting periods (days after emergence for Nigeria, Kenya and Rwanda; days after planting for Sierra Leone) followed at each intermediate dry matter determination in different experiments.

\begin{tabular}{lccc}
\hline Experiment & First harvest & Second harvest & Third harvest \\
\hline Nigeria & 21 & 26 & 31 \\
Kenya & 14 & 21 & 28 \\
Rwanda & 14 & 26 & 34 \\
Sierra Leone & 15 & 20 & 25 \\
\hline
\end{tabular}

recorded, followed by oven drying of plant shoots at $60^{\circ} \mathrm{C}$ to constant weight.

\section{Calculations}

Biomass accumulation in treatments where a single nutrient had been omitted was compared with the biomass in the treatment with all nutrients applied, which is expected to have the largest biomass accumulation due to optimal conditions for growth. The concept of sufficiency quotient (Janssen, 1974) was used to measure availability of nutrients in a specific soil. Nutrient sufficiency quotient (SQ) is an index of the difference in growth between plants on a deficient and on a complete solution, because of the difference in nutrient availability. It may be estimated by determining the relative increase in plant weight (Rs) and the mean growth rate of plants at given time $t$ as follows:

$$
\mathrm{Rs}=(1 / \mathrm{S})(\mathrm{dS} / \mathrm{dt})
$$

where Rs is the relative growth rate; $\mathrm{S}=$ shoot dry weight in $\mathrm{g}$ and $\mathrm{t}=$ time in days.

Because of exponential growth, the mean growth at any given time is then estimated using the relation;

$$
\mathrm{Rs}=(\ln \mathrm{S} 2-\ln \mathrm{S} 1) /(\mathrm{t} 2-\mathrm{t} 1)
$$

The SQ of respective nutrient elements are estimated as;

$$
\mathrm{SQ}_{\mathrm{x}}=(\mathrm{Rs})-\mathrm{x} /(\mathrm{Rs}) \mathrm{C}
$$

Where; $S Q_{\mathrm{x}}=$ sufficiency quotient for nutrient element in question, (Rs)- $\mathrm{x}=$ Relative growth rate of plants growing in nutrient solutions with $\mathrm{x}$ (nutrient element) omitted and (Rs) $\mathrm{C}=$ Relative growth rate of plants growing on complete nutrient solution. Since the exact variance of a ratio of Rs-X and $\mathrm{Rs}-\mathrm{C}$ is undefined, we express the relative deficiency as a difference, rather than a ratio, so that the standard error of the estimate can be calculated exactly using the statistical procedure described below.

We thereby define the sufficiency difference $\mathrm{SD}_{\mathrm{x}}$, as:

$$
\mathrm{SD}_{\mathrm{x}}=(\mathrm{Rs})-\mathrm{x}-(\mathrm{Rs}) \mathrm{C}
$$

Values of $\mathrm{SD}_{\mathrm{x}}$ significantly less than 0 provide evidence for deficiency of that particular nutrient.

\section{Statistical Analysis}

Statistical analysis was done using the programming language $\mathrm{R}$ (version 2.15.1). Data consisted of shoot dry weights (dwt_shoot) measured at three time points (time) for three to four replicates per soil and omitted nutrient (omitted_nutrient).

To evaluate evidence for deficiency of individual nutrients in the soil, the following linear mixed model was used to estimate the relative growth of each omitted nutrient treatment:

$$
\begin{aligned}
\ln \left(d w t \_s h o o t\right) \sim & \text { soil }+ \text { soil }: \text { omitted_nutrient }+ \text { soil }: \text { time } \\
& + \text { soil }: \text { omitted_nutrient }: \text { time }
\end{aligned}
$$

A soil and replication specific time term was added as a random effect to account for repeated measurement in time by modeling the average growth per soil per replicate. The fixed terms soil and soil:time represent the average intercept and growth rate per soil. The complete nutrient treatment was defined as the reference level such that the coefficients for the interaction term interaction soil:omitted_nutrient corresponds to the difference in $\ln \left(d w t_{\text {_sshoot }}\right.$ of each omission treatment for a particular soil with respect to the complete treatment at $\mathrm{t}=0$ and the coefficient for the interaction term: soil:omitted_nutrient:time represents the soil-specific regression slope of $\ln \left(d w t_{-}\right.$shoot) against time, relative to the complete nutrient solution. As such, the latter provides a direct estimate of the sufficiency difference, $\mathrm{SD}_{\mathrm{x}}$ for the different omitted nutrients, with a significantly negative t-statistic indicating deficiency.

Similarly, the model: $\ln \left(d w t_{-}\right.$shoot $) \sim$ soil+soil:omitted_nutrient was used to evaluate the effects of specific nutrient deficiencies in individual soils on average 
shoot biomass accumulation. Data points with residuals larger or smaller than 4 standard deviations were removed before fitting final models for estimation.

Soil parameters were summarized per country and their pairwise correlations were calculated and visualized with bi-plots based on principal component analysis of the scaled parameters. The relationship between values of $\mathrm{SD}_{\mathrm{x}}$ and average biomass for different soils and individual soil parameters was evaluated by linear regression with a correction for country.

\section{RESULTS}

\section{Visual Deficiency Symptoms}

In most cases, multiple deficiency symptoms occurred on the same plant simultaneously (Table 5). Deficiencies manifested by necrosis and yellowing of older leaves were common in all experimental soils and treatments, with severe symptoms recorded on $-\mathrm{P}$ and $-\mathrm{K}$ treatments in Kenya and Rwanda. $\mathrm{P}$ deficient plants were observed across soils in Kenya and Sierra Leone with Control and -P treatments. K deficiency symptoms were evident at an early growth stage (10 to $12 \mathrm{DAE})$ in the Control in Rwanda and across experimental soils in Kenya, Rwanda and Sierra Leone with the $-\mathrm{K}$ treatments. Mg deficiency symptoms were observed across soils and treatments in Rwanda, and in all soils in Kenya and Nigeria under $-\mathrm{Mg}$ treatment. Symptoms of Mo deficiency were observed on soil Masaba from Kenya with - MN treatment, and across soils from Nigeria under the Control and -MN treatments.

\section{Sufficiency Difference for Omitted Nutrients}

One soil from Soba, Nigeria had significantly negative sufficiency differences for all tested nutrient treatments (Table 6). Of the 16 remaining soils, 10 soils showed growth reduction due to deficiencies in one or more nutrients, with $-\mathrm{K}$ (9 soils), -P (4 soils), -Mg (4 soils), -S (two soils) and -MN (2 soils) treatments having sufficiency differences significantly below 0 (Table 5). Potassium (K) deficiency was observed in Butula and Masaba soils in Kenya, Garko and Soba soils in Nigeria, Cyabingo, Musambira, and Nyarubaka soils in Rwanda, as well as Bondajuma and Kodenbotihun soils in Sierra Leone. Significant $\mathrm{P}$ deficiency was observed in Bondajuma, Foya Junction and Kodenbotihun soils in Sierra Leone and Soba soil in Nigeria. Magnesium (Mg) deficiency was found to reduce growth in soil Kakamega 2 in Kenya and soils Cyabingo and Musambira in Rwanda. Poor growth due to micronutrient deficiency was only detected on the Rwandan Musambira soil. Interestingly, three of the soils with evidence for nutrient deficiencies, had the controls not showing significant reduction in growth rate.

\section{Relative Shoot Biomass}

Results for relative shoot biomass (Table 7), revealed more evidence for nutrient deficiency than growth rate. In addition to the Nigerian Soba soil, which again had significantly reduced biomass for all nutrient treatments except S, 16 soils were deficient for one or more nutrients. Potassium deficiency was again the most common (14

TABLE 5 | Symptoms of deficiency of nutrients (in bracket) and period when first observed on plants growing on a particular experimental soils for different treatments.

\begin{tabular}{|c|c|c|c|c|}
\hline Treatment & Kenya & Nigeria & Rwanda & Sierra Leone \\
\hline Control & $\begin{array}{l}\text { From } 10 \text { DAE, in all soils; stunted } \\
\text { plants with dark green leaves }(P)\end{array}$ & $\begin{array}{l}\text { From } 17 \text { DAE, in all soils; reddish } \\
\text { spots, interveinal chlorosis and } \\
\text { yellowing of older leaves (N, Mg, } \\
\text { Mo) }\end{array}$ & $\begin{array}{l}\text { From } 12 \text { DAE, in all soils; } \\
\text { yellowing and necrosis of } \\
\text { margins of older leaves, early leaf } \\
\text { drop ( } \mathrm{N}, \mathrm{K} \text { and } \mathrm{Mg} \text { ) }\end{array}$ & $\begin{array}{l}\text { From } 12 \text { DAE, in all soils stunted } \\
\text { plants with dark green leaves }(P)\end{array}$ \\
\hline Complete & $\begin{array}{l}\text { From } 20 \text { DAE, in all soils; yellowing } \\
\text { of older leaves }(\mathrm{N})\end{array}$ & No observed deficiency symptoms & $\begin{array}{l}\text { From } 17 \text { DAE, in all soils; older } \\
\text { leaves yellow ( } \mathrm{N}, \mathrm{Mg})\end{array}$ & $\begin{array}{l}\text { From } 20 \text { DAE, in all soils; older } \\
\text { leaves deep yellow }(\mathrm{N})\end{array}$ \\
\hline$-P$ & $\begin{array}{l}\text { From } 15 \text { DAE, in all soils; stunted } \\
\text { plants with dark green younger } \\
\text { leaves, older leaves deep } \\
\text { yellow }(\mathrm{N}, \mathrm{P})\end{array}$ & $\begin{array}{l}\text { From } 12 \text { DAE, in all soils; yellowing } \\
\text { of older leaves }(\mathrm{N})\end{array}$ & $\begin{array}{l}\text { From } 17 \text { DAE; in all soils, } \\
\text { yellowing of older leaves with } \\
\text { severe interveinal chlorosis } \\
(\mathrm{N}, \mathrm{Mg})\end{array}$ & $\begin{array}{l}\text { From } 12 \text { DAE, in all soils stunted } \\
\text { plants with dark green young leaves } \\
(\mathrm{P}) \text {, old leaves yellow }(\mathrm{N})\end{array}$ \\
\hline$-K$ & $\begin{array}{l}\text { From } 12 \text { DAE, in Masaba soils; older } \\
\text { leaves pale yellow, necrotic, leaves } \\
\text { dropping early ( } \mathrm{N}, \mathrm{K}, \mathrm{Mg})\end{array}$ & No observed deficiency symptoms & $\begin{array}{l}\text { From } 12 \text { DAE, in all soils; older } \\
\text { leaves pale yellow, strongly } \\
\text { necrotic and dropping. Severe in } \\
\text { soil Cyabingo and soil } \\
\text { Musambira (N, K, Mg). }\end{array}$ & $\begin{array}{l}\text { From } 12 \text { DAE, in all soils; yellowing } \\
\text { of older leaves, grey-brown spot } \\
\text { progressive from older to younger } \\
\text { leaves }(\mathrm{N}, \mathrm{K})\end{array}$ \\
\hline$-\mathrm{Mg}$ & $\begin{array}{l}\text { From } 10 \mathrm{DAE} \text {, in all soils; interveinal } \\
\text { chlorosis yellowing of older leaves, } \\
\text { early leaf drop (Mg, } \mathrm{K} \text { ) }\end{array}$ & $\begin{array}{l}\text { From } 11 \text { DAE, in all soils; interveinal } \\
\text { chlorosis on older leaves, severe on } \\
\text { plant growing in soil Garko (Mg) }\end{array}$ & $\begin{array}{l}\text { From } 10 \mathrm{DAE} \text {, in all soils; older } \\
\text { leaves chlorotic and necrotic, } \\
\text { severe in soil Cyabingo and soil } \\
\text { Musambira (K, Mg) }\end{array}$ & No observed deficiency symptoms \\
\hline$-S$ & $\begin{array}{l}\text { From } 20 \text { DAE, in Masaba and Butere } \\
\text { soils; younger and older leaves pale } \\
\text { (S) }\end{array}$ & No observed deficiency symptoms & $\begin{array}{l}\text { No observed deficiency } \\
\text { symptoms }\end{array}$ & No observed deficiency symptoms \\
\hline$-M N$ & $\begin{array}{l}\text { From } 20 \text { ADE, across soils; Irregular } \\
\text { leaves, thick and brittle, dark brown } \\
\text { with irregular lesions progressing to } \\
\text { necrosis (Mo, Bo) }\end{array}$ & $\begin{array}{l}\text { From } 17 \text { DAE, in all soils; thick pale } \\
\text { leaves, scorched and rolled younger } \\
\text { leaves }(\mathrm{Mo}, \mathrm{N})\end{array}$ & $\begin{array}{l}\text { From } 12 \text { DAE, older leaves } \\
\text { yellow with interveinal chlorosis } \\
(\mathrm{N}, \mathrm{Mg})\end{array}$ & No observed deficiency symptoms \\
\hline
\end{tabular}


TABLE 6 | Averages of the sufficiency difference of control and omitted nutrients (relative to complete) ordered per experimental soil and per $P$ values.

\begin{tabular}{|c|c|c|c|c|c|c|c|}
\hline \multirow[t]{2}{*}{ Country } & \multirow[t]{2}{*}{ Soil } & \multicolumn{6}{|c|}{ Treatment } \\
\hline & & Control & $-P$ & $-K$ & $-M g$ & $-S$ & MN \\
\hline \multirow[t]{3}{*}{ Kenya } & Butula & -0.008 & ns & -0.049 & -0.061 & ns & ns \\
\hline & Kakamega2 & -0.006 & ns & ns & ns & ns & ns \\
\hline & Masaba & -0.011 & ns & -0.071 & ns & ns & ns \\
\hline \multirow[t]{3}{*}{ Nigeria } & Garko & -0.073 & ns & -0.062 & ns & ns & ns \\
\hline & Kachia & -0.037 & ns & ns & ns & ns & Ns \\
\hline & Soba & -0.121 & -0.087 & -0.106 & -0.073 & -0.105 & -0.097 \\
\hline \multirow[t]{4}{*}{ Rwanda } & Cyabingo & -0011 & ns & -0.050 & -0.049 & ns & ns \\
\hline & Kawangile & -0.042 & ns & -0.023 & Ns & ns & ns \\
\hline & Musambila & -0.011 & ns & ns & -0.047 & ns & ns \\
\hline & Nyarubaka & -0.002 & ns & -0.065 & ns & ns & ns \\
\hline \multirow[t]{5}{*}{ Sierra-Leone } & Bondajuma & -0.049 & -0.069 & -0.071 & ns & -0.009 & ns \\
\hline & Foya Junction & -0.059 & -0.135 & ns & ns & ns & -0.035 \\
\hline & Gbombtrait & -0.096 & ns & ns & ns & ns & ns \\
\hline & Kodenbotihun & -0.122 & -0.120 & -0.098 & ns & ns & ns \\
\hline & MeriCurve & -0.041 & ns & ns & $\mathrm{ns}$ & ns & ns \\
\hline
\end{tabular}

Except for the Control, results are for treatments where values for sufficiency differences were significantly below zero (0), ns = not significant.

TABLE 7 | Averages of log biomass of control and omitted nutrients (relative to Complete) that were significantly below zero (0) ordered per experiment soil, ns = not significant.

\begin{tabular}{|c|c|c|c|c|c|c|c|}
\hline \multirow[t]{2}{*}{ Experiment } & \multirow[t]{2}{*}{ Soil } & \multicolumn{6}{|c|}{ Treatments } \\
\hline & & Control & $-P$ & $-K$ & $-M g$ & $-S$ & MN \\
\hline \multirow[t]{5}{*}{ Kenya } & Butula & -0.471 & $-0.310^{*}$ & -0.678 & -0.361 & ns & ns \\
\hline & Butere & -0.521 & $-0.325^{\star}$ & -0.649 & -0.358 & ns & ns \\
\hline & Kakamega 1 & -0.519 & -0.317 & -0.307 & ns & $\mathrm{ns}$ & ns \\
\hline & Kakamega 2 & -0.418 & ns & -0.638 & ns & ns & ns \\
\hline & Masaba & -0.541 & ns & -0.571 & ns & ns & ns \\
\hline \multirow[t]{3}{*}{ Nigeria } & Garko & -0.486 & -0.444 & ns & ns & -0.351 & ns \\
\hline & Kachia & -0.887 & -0.763 & -0.623 & ns & ns & ns \\
\hline & Soba & -1.057 & -0.873 & -0.929 & -0.516 & ns & -0.516 \\
\hline \multirow[t]{4}{*}{ Rwanda } & Cyabingo & -0.507 & ns & -0.891 & -0.381 & ns & ns \\
\hline & Kawangire & -0.119 & ns & -0.765 & -0.414 & ns & ns \\
\hline & Musambira & -0.232 & ns & -0.724 & $\mathrm{~ns}$ & ns & ns \\
\hline & Nyarubaka & -0.204 & ns & -0.817 & -0.364 & ns & Ns \\
\hline \multirow[t]{5}{*}{ Sierra Leone } & Bondajuma & -0.616 & -0.347 & -0.371 & Ns & -0.417 & ns \\
\hline & Gbombrait & -0.603 & -0.639 & -0.451 & Ns & ns & ns \\
\hline & Kondenbothium & -0.722 & -0.385 & -0.527 & Ns & ns & ns \\
\hline & MeriCurve & -0.827 & -0.595 & ns & ns & ns & ns \\
\hline & Foya Junction & -1.088 & ns & -0.654 & -0.358 & ns & ns \\
\hline
\end{tabular}

soils), followed by phosphorus (10 soils), magnesium (8 soils), sulfur (2 soils) and micronutrients (1 soil). With the exception of soil Musambira in Rwanda, relative shoot biomass was significantly reduced in more than one nutrient treatment, and out of seventeen deficient soils, the relative biomass in the control treatment (no nutrient added) was significantly lower than in the complete nutrient solution in fourteen soils.

\section{Relationships Between Sufficiency Difference and Relative Shoot Biomass}

Overall, the correlation between the sufficiency difference and relative shoot biomass was moderate though highly significant $\left(R^{2}=0.30, p<0.0001\right.$ ) (Figure 3). Out of 101 soil/nutrient combinations only 22 were significant for both measures. Significant results for growth were basically a subset of those for biomass, with only three instances where a significant 


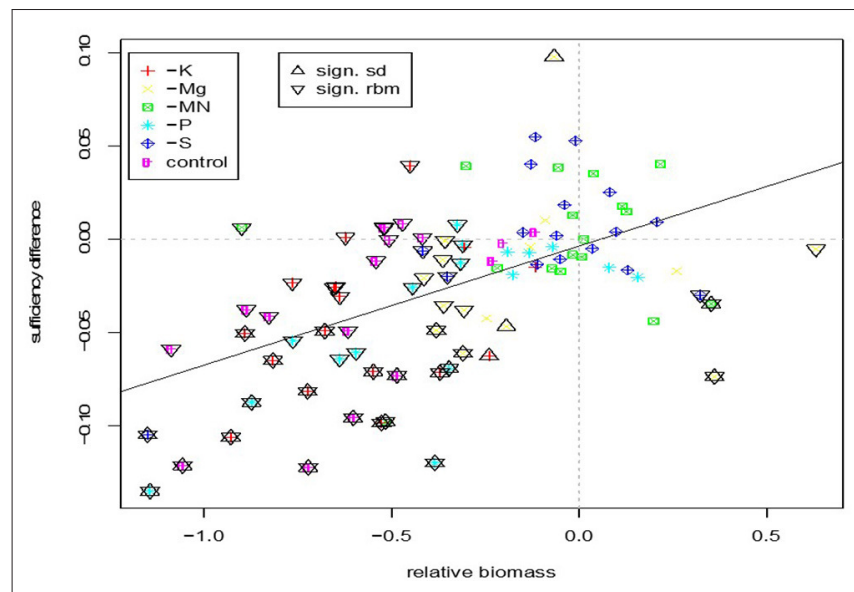

FIGURE 3 | Relationship between sufficiency difference and relative biomass for the different nutrients in specific soils. Significant values are marked by up and down facing triangles for sufficiency difference and relative biomass, respectively. Stars indicate simultaneous significance for relative biomass and sufficiency difference.

soil/nutrient combination was not significant for biomass. In contrast, 34 soil/nutrient combinations with significant reduction in biomass were not significant for growth. Considering significant results over both methods suggests that deficiencies of $\mathrm{K}, \mathrm{P}, \mathrm{Mg}$, S, and $\mathrm{MN}$ occured in $82,59,47,12$, and $6 \%$ of tested soils, respectively.

\section{Relationship Between Soil Properties and Nutrient Deficiencies}

Overall, weak relationships between specific nutrient deficiencies and individual soil properties were observed (Figure 4). Of all the relations tested, only soil $\mathrm{N}$ and $\mathrm{K}$ concentration had a significant relationship with $-\mathrm{K}$ for growth rate and with $\mathrm{Mg}$ and $-\mathrm{P}$ for relative shoot biomass. Nutrient deficiency was never significantly correlated with the soil concentration of the missing nutrient.

\section{DISCUSSION}

This study was the first to evaluate deficiencies of individual nutrients constraining legume growth in a diverse sample of "non-responsive" soils from SSA, providing evidence on the missing elements that could contribute to poor yields and nutrient responses in the region. Visual deficiency symptoms and decreased growth, as measured by sufficiency difference and mean shoot biomass, revealed that $\mathrm{K}, \mathrm{P}, \mathrm{Mg}$ and to lesser extent $\mathrm{S}$, and $\mathrm{MN}$ were limiting legume production in the tested soils. Overall, all the tested soils lacked at least one nutrient, with the occurrence and extent of deficiency varying between soils within and across countries. This variability confirms that soil nutrient limitations are spatially heterogeneous, supporting the notion that soil fertility management amendments on smallholder farms in SSA could be improved by tailoring to local conditions (Giller et al., 2011; Vanlauwe et al., 2015). Our results confirm other studies reporting wide-spread deficiencies of $\mathrm{P}$ and, to a lesser extent $\mathrm{S}$, on maize in soils of West African savanna (Vanlauwe et al., 2002; Franke et al., 2008; Nziguheba et al., 2009, 2016) and in soils of eastern and southern Africa, including Western Kenya (Kihara et al., 2016), although evidence for deficiencies of $\mathrm{K}, \mathrm{Mg}$, and micronutrients in the literature is relatively rare (Van der Zaag, 2010).

It is noteworthy therefore that $\mathrm{K}$ and $\mathrm{Mg}$ deficiencies were frequently detected in the present study, suggesting that these nutrients are perhaps a frequent cause of the lack of response to $\mathrm{P}$ and rhizobial inoculation. Although further confirmation is needed through field trials it is likely that including $\mathrm{K}$ and $\mathrm{Mg}$ in legume-specific fertilizers could improve legume yields where non-responsive soils are frequent. Similarly, the limitations found for $\mathrm{S}$ and micronutrients (usually in association with $\mathrm{P}$ or $\mathrm{K}$ deficiency) are an indication that limitations of secondary and micronutrients are locally important but less frequent. With many countries in SSA becoming progressively committed to a policy of agricultural intensification, adequate availability of these nutrients can no longer be taken for granted since the use of improved crop varieties with only $\mathrm{N}$ and $\mathrm{P}$ fertilization will in the long-term invariably lead to greater crop removal and deficiencies of other nutrients. Application of secondary and $\mathrm{MN}$ on soils revealing secondary nutrient limitations is one of the effective ways to enhance fertilizer use efficiency, and this can be done efficiently by blending commonly available NPK fertilizers with secondary and micronutrients (Vanlauwe et al., 2015). Legume-specific fertilizers with a wider blend of nutrients have been developed and marketed in several countries of sub-Saharan Africa based on this work (Giller and Ronner, 2019).

Two other notable results in our study were the multiple deficiencies observed for the soil from Soba in Nigeria and the absence of $\mathrm{P}$ deficiency in Rwandan soils. We have no clear explanation for the former observation but absence of $\mathrm{P}$ limitation in Rwanda soils was possibly a result of extensive use of P-fertilizers stimulated by the governmentsupported program on crop intensification (Ndushabandi et al., 2018). The crop intensification programme in Rwanda provides subsidies on fertilizers and seeds and support farmers to market their crops.

Janssen (1990) quantified nutrient deficiency by the reduction in growth rate. Here we applied a statistical model to get accurate estimates of this reduction and corresponding mean relative biomass in a replicated experiment. Although correlation between both measures of nutrient deficiency was moderate, relative biomass estimation yielded more significant deficiencies than the sufficiency difference (Figure 2), suggesting superior sensitivity. It is possible that estimates of growth are sensitive to deviations from linearity in the measured time period. The fact that our growth measurements started relatively late (10$15 \mathrm{DAE}$ ), to elimate effects of seed nutrients, might have caused measures of slope (i.e., sufficiency difference) to be estimated less reliably. Nevertheless, our results suggest that relying on growth estimates alone may not be the best approach and that average relative biomass offers an appropriate measure of deficiency. 

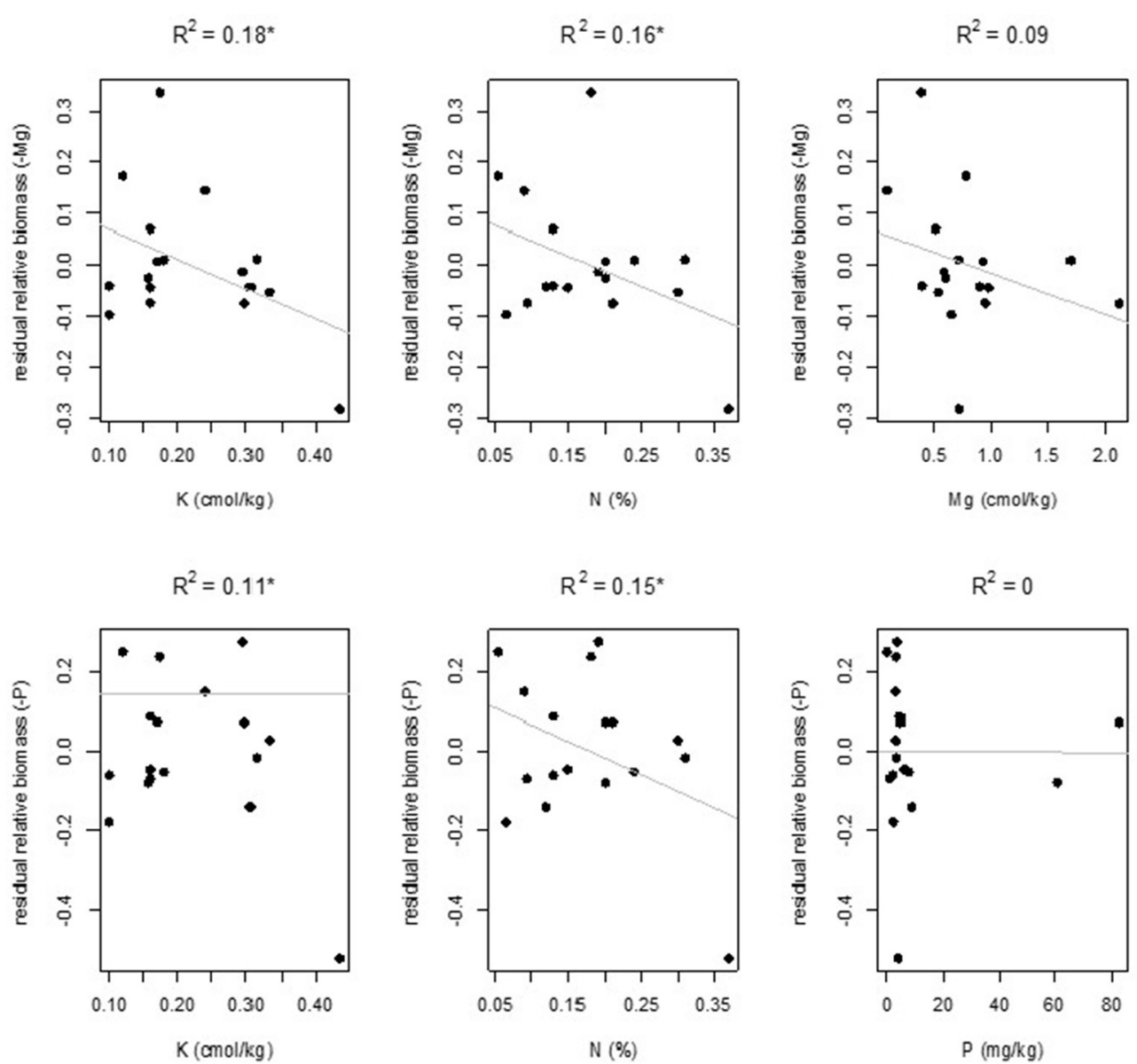

FIGURE 4 | Plots showing the relation between sufficiency difference (upper row) and relative shoot biomass (lower two rows) and soil parameters for the cases where a significant relationship was found (indicated by an asterisk) and for soil content of the missing nutrient. Top row from left to right: growth reduction for - $\mathrm{K}$, against $\mathrm{N}$ (\%) and $\mathrm{K}(\mathrm{cmol} / \mathrm{kg})$. Second row left to right: biomass reduction for $-\mathrm{Mg}$, against $\mathrm{K}(\mathrm{ppm}) \mathrm{N}(\%)$ and $\mathrm{Mg}(\mathrm{ppm})$. Bottom row left to right: biomass reduction for $-\mathrm{P}$, against $\mathrm{K}(\mathrm{cmol} / \mathrm{kg}) \mathrm{N}(\%)$ and $\mathrm{P}(\mathrm{mg} / \mathrm{kg})$. Results are shown for the model residuals after correcting for country.

\section{CONCLUSIONS}

The present study examined a small range of soils from selected farmers' fields in four countries in SSA, identified nutrients limiting legume growth and provided data relevant for developing strategies and identified possible solutions to improve legume productivity. The double pot technique used here may not be as reliable as field experiments for soil nutrient diagnosis but the results nonetheless shed light on nutrients which could raise yields of legumes grown in soils with similar characteristics to those tested here. Based on our sample, and assuming representability, deficiencies of $\mathrm{K}, \mathrm{P}, \mathrm{Mg}, \mathrm{S}$ and micronutrients seem to be wide-spread in non-responsive soils and were detected in $88,65,59$, 18 , and $18 \%$ of the soils, respectively. If these deficiencies indeed translate to reduced yields under field conditions, ignoring them will harm prospects for sustainable agricultural intensification in smallholder production. In that case, strategies for improvement of legume productivity should consider among others, blending of commonly available NPK fertilizers with secondary nutrients like $\mathrm{Mg}$ and $\mathrm{S}$, and the $\mathrm{MN}$, and organic resources amendments including animal manure (where available) to achieve a balanced crop nutrition. Application of these should take into account a targeted approach to address soil-specific deficient nutrients for a more efficient use of fertilizers and other inputs. Research is needed to verify the current results under field conditions and to define the extent of secondary and micronutrients limitation to crop growth in SSA.

\section{DATA AVAILABILITY STATEMENT}

The raw data supporting the conclusions of this article will be made available by the authors, upon request without undue reservation. 


\section{AUTHOR CONTRIBUTIONS}

All authors listed have made a substantial, direct and intellectual contribution to the work, and approved it for publication.

\section{FUNDING}

We thank the Bill \& Melinda Gates Foundation for funding through a grant number OPP1020032 to Wageningen University

\section{REFERENCES}

Bevis, L. E. (2015). Soil-to-human mineral transmission with an emphasis on zinc, selenium, and iodine. Sci. Rev. 3, 77-96. doi: 10.1007/s40362-014-0026-y

Franke, A. C., Laberge, G., Oyewole, B. D., and Schulz, S. (2008). A comparison between legume technologies and fallow, and their effects on maize and soil traits, in two distinct environments of the West African savannah. Nutr. Cycl. Agroecosyst. 82, 117-135. doi: 10.1007/s10705-008-9174-2

Franke, A. C., van Den Brand, G. J., Vanlauwe, B., and Giller, K. E. (2017). Sustainable intensification through rotation with grain legumes: a review. Agri. Ecosyst. Envir. 261, 172-185. doi: 10.1016/j.agee.2017.09.029

Gee, W. G., and Or, D. (2002). "Particle-Size Analysis", in Methods of Soil Analysis. Book Series: 5 Part 4, eds. J. Dane and G.C. Topp (Soil Science Society of America), 255-293.

Gibson, D. J., Connolly, J., Hartnett, D. C., and Weidenhamer, J. D. (1999). Designs for greenhouse studies of interactions between plants. J. Ecol. 87, 1-16. doi: 10.1046/j.1365-2745.1999.00321.x

Giller, K. E., Franke, A. C., Abaidoo, R., Baijukya, F., Bala, A., Boahen, S., et al. (2013). "N2Africa: putting nitrogen fixation to work for smallholder farmers in Africa", in Agro-ecological Intensification of Agricultural Systems in the African Highlands, eds. B. Vanlauwe, P.J.A. van Asten and G. Blomme (London: Routledge), 156-174.

Giller, K. E., and Ronner, E. (2019). The Story of N2Africa: Putting Nitrogen Fixation to Work for Smallholder Farmers in Africa. Wageningen: Wageningen University and Research. Available online at: https://edepot.wur.nl/527074

Giller, K. E., Tittonell, P., Rufino, M. C., Van Wijk, M., Zingore, S., Mapfumo, P., et al. (2011). Communicating complexity: Integrated assessment of trade-offs concerning soil fertility management within African farming systems to support innovation and development. Agric. Syst. 104, 191-203. doi: 10.1016/j.agsy.2010.07.002

Hewitt, E. J. (1966). Sand and Water Culture Methods Used in the Study of Plant Nutrition. Technical Communication no 22 (revised). Commonwealth Bureau of Horticulture and Plantation Crops. East Malling, Maidstone, Kent, England.

Janssen, B. H. (1974). A double pot technique for rapid soil testing. Tropic. Agricult. 51:2.

Janssen, B. H. (1990). "A double pot technique as a tool in plant nutrition studies", in Plant Nutrition-Physiology and Applications. Development in Plant and soil Sciences Volume 41, ed. M.L. van Beusichem (Kluwer, Dordrecht), 759-763.

Keino, L., Baijukya, F. P., Ng'etich, W., Otinga, A. N., Okalebo, J. R., Njoroge, R., et al. (2015). Nutrients limiting soybean (Glycine max L.) growth in Acrisols and Ferralsols of Western Kenya. PLoS ONE 10:145202. doi: 10.1371/journal.pone.0145202

Kihara, J., Nziguheba, G., Zingore, S., Coulibaly, A., Elisaba, A., Kabambe, V., et al. (2016). Understanding variability in crop response to fertilizer and amendments in sub-Saharan Africa. Agric. Ecosyst. Envir. 229, 1-12. doi: 10.1016/j.agee.2016.05.012

Landon, J. R. (1991). Booker Tropical Soil Manual: A Handbook for Soil Survey and Agricultural Land Evaluation in the Tropics and Subtropics. New York, NY: John Wiley and Sons, Inc, 133-135.

Latham, M. C. (1997). Human Nutrition in the Developing World. FAO food and nutrition ser. no. 29, Rome. to support the project N2Africa: Putting Nitrogen Fixation to Work for Smallholder Farmers in Africa (www.N2Africa.org).

\section{ACKNOWLEDGMENTS}

We are grateful to the management of IITA-Kano station, Rwanda Agricultural Board at Rubona Station, University of Eldoret, Kenya and Sierra Leone Agricultural Research Institute (SLARI) in Sierra Leone for providing the space to conduct the experiments. Anne de Valença is acknowledged for helping in formatting and cleaning the data.

Mehlich, A. (1984). Mehlich 3 soil extractant: a modification of Mehlich 2 extractant. Commun. in Soil Sci. Plant Anal. 15, 1409-1416. doi: 10.1080/00103628409367568

Ndushabandi, E. N., Rutayisoma, C., Mwangi, L., and Bizimana, V. (2018). Crop Intensification Program (CIP) Citizen's Satisfaction Survey. Institute of Research and Dialogue for Peace (IRDP), Kigali Rwanda, 86.

Nedumaran, S., Abinaya, P., Jyosthnaa, P., Shraavya, B., Parthasarathy, R., and Cynthia, B. (2015). Grain legumes production, consumption and trade trends in developing countries. Working Paper Series No 60. ICRISAT Research Program, Markets, Institutions and Policies. Patancheru 502 324, Telangana, India: International Crops Research Institute for the Semi-Arid Tropics.

Nelson, D. W., and Sommers, L. E. (1982). "Total carbon, organic carbon and organic matter”, in Methods of soil analysis. Part 2 Chemical and Microbiological Properties, Agronomy Series No. 9, eds. A.L. Page, R.H. Miller and D.R. Keeney (ASA SSSA, Madison), 539-579.

Nziguheba, G., Tossah, B. K., Diels, K., Franke, A. C., Aihou, K., Iwuafor, E. N. O., et al. (2009). Assessment of nutrient deficiencies in maize in nutrient omission trials and long-term field experiments in the West African Savanna. Plant Soil 314, 143-157. doi: 10.1007/s11104-0089714-1

Nziguheba, G., Zingore, S., Kihara, J., Merckx, R., Njoroge, S., and Otinga, A., et al. (2016). Phosphorus in smallholder farming systems of sub-Saharan Africa: implications for agricultural intensification. Nutr. Cycl. Agroecosystems 104, 321-340. doi: 10.1007/s10705-015-9729-y

Odendo, M., Bationo, A., and Kimani, S. (2011). "Socio-economic contribution of legumes to livelihoods in sub-Saharan Africa", in Fighting Poverty in subSaharan Africa: The Multiple Roles of Legumes in Integrated Soil Fertility Management, eds. A. Bationo, B. Waswa, J. Okeyo, F. Maina, J. Kihara and U. Mokwunye (Dordrecht: Springer), 27-46.

Paradiso, R., Buonomo, R., De Micco, V., Aronne, G., Palermo, M., Barbieri, G., et al. (2012). Soybean cultivar selection for bioregenerative life support systems (BLSSs)-hydroponic cultivation. Adv. Space Res. 50, 1501-1511. doi: 10.1016/j.asr.2012.07.025

Ronner, E., Franke, A. C., Vanlauwe, B., Dianda, M., Edeh, E., Ukem, B., et al. (2016). Understanding variability in soybean yield and response to P-fertilizer and rhizobium inoculants on farmers' fields in northern Nigeria. Field Crop Res. 186, 133-145. doi: 10.1016/j.fcr.2015.10.023

Sanchez, P. A., Shepherd, J. D., Soule, M. J., Place, F. M., Bureish, R. J., Izac, A. N., et al. (1997). "Soil Fertility Replenishment in Africa: An investment in Natural Resource Capital”, in Replenishing Soil Fertility, Africa, eds R.J. Buresh, P.A. Sanchez and F. Calhoun, SSSA Special Publication No 51 (Madison: Soil Science Society of America.), 1-46.

Savadogo, M., Zemmelink, G., van Keulen, H., and Nianogo, A. J. (2000). Cowpea and groundnut haulms as supplements to sorghum stover: intake, digestibility and optimum feeding in Djallonke rams. Anim. Feed Sci. Technol. 87:57-69 doi: 10.1016/S0377-8401(00)00185-1

Smith, L. C., and Haddad, L. (2014). Reducing child undernutrition: past drivers and priorities for the post-MDG Era. World Dev. 68, 180-204. doi: 10.1016/j.worlddev.2014.11.014

Somasegaran, P., and Hoben, H. J. (1994). Handbook for Rhizobia. Methods in Legume-Rhizobium Technology. New York, NY: Springer-Verlag, 240-58. 
Tarawali, G., and Mohamed-Saleem, M. A. (1995). "The role of forage legume fallows in supplying improved feed and recycling nitrogen in sub-humid Nigeria," in Livestock and Sustainable Nutrient Cycling in Mixed Farming Systems of Sub-Saharan Africa. Volume II: Technical Papers. Proceedings of an international conference held in Addis Ababa, Ethiopia, 22-26th November, 1993. ILCA, ed J.M. Powell (International Livestock Centre for Africa, Addis Ababa, Ethiopia).

Thomas, G. W. (1982). "Extractable Cations", in Methods of Soil Analysis. Part 2 Chemical and Microbiological Properties, eds. A.I. Page, R.H., Millet, D.R., Keeney (ASSA, CSSA, SSSA, Wisconsin, MA), 539-579.

Van der Zaag, P. (2010). Viewpoint-Water variability, soil nutrient heterogeneity and market volatility-Why sub-Saharan Africa's Green Revolution will be location-specific and knowledge-intensive. Water Altern. 3, 154-160. doi: 10.1007/s13280-012-0359-1

Van Heerwaarden, J., Baijukya, F. P., Kyei-Boahen, S., Adjei-Nsiah, S., Ebanyat, P., Kamai, N., et al. (2018). Soyabean response to rhizobium inoculation across sub-Saharan Africa: Patterns of variation and the role of promiscuity. Agric. Ecosyst. Environ. 261, 211-218. doi: 10.1016/j.agee.2017.08.016

Vanlauwe, B., Descheemaeker, K., Giller, K. E., Huising, J., Merckx, R., and Nziguheba, G., et al. (2015). Integrated fertility management in sub-Saharan Africa: unravelling local adaptation. SOIL 1, 491-508 doi: 10.5194/soil-1-491-2015

Vanlauwe, B., Diels, J., Lyasse, O., Aihou, K., Iwuafor, E. N. O., Sanginga, N., et al. (2002). Fertility status of soils of the derived savanna and northern guinea savanna and response to major plant nutrients, as influenced by soil type and land use management. Nutr. Cycl. Agroecosystems 62, 139-150 doi: 10.1023/A:1015531123854

Vanlauwe, B., Hungria, M., Kanampiu, F., and Giller, K. E. (2019). The role of legumes in the sustainable intensification of African smallholder agriculture: lessons learnt and challenges for the future. Agric. Ecosyst. Environ. 284:106583, doi: 10.1016/j.agee.2019. 106583

Conflict of Interest: The authors declare that the research was conducted in the absence of any commercial or financial relationships that could be construed as a potential conflict of interest.

Publisher's Note: All claims expressed in this article are solely those of the authors and do not necessarily represent those of their affiliated organizations, or those of the publisher, the editors and the reviewers. Any product that may be evaluated in this article, or claim that may be made by its manufacturer, is not guaranteed or endorsed by the publisher.

Copyright (C) 2021 Baijukya, Van Heerwaarden, Franke, Van den Brand, Foli, Keino, Seitz, Servan, Vanlauwe and Giller. This is an open-access article distributed under the terms of the Creative Commons Attribution License (CC BY). The use, distribution or reproduction in other forums is permitted, provided the original author(s) and the copyright owner(s) are credited and that the original publication in this journal is cited, in accordance with accepted academic practice. No use, distribution or reproduction is permitted which does not comply with these terms. 